\title{
PELAKSANAAN LAYANAN BIMBINGAN KELOMPOK TERHADAP PENURUNAN KENAKALAN REMAJA DI SMK NEGERI 1 SIPIROK
}

\author{
${ }^{1}$ Vitria Larseman Dela, ${ }^{2}$ Asmaryadi, ${ }^{3}$ Khairul Amri \\ Prodi Bimbingan dan Konseling, FKIP Universitas Muhammadiyah Tapanuli Selatan \\ vitria.larseman@um-tapsel.ac.id
}

\begin{abstract}
This research is based on the probtem that there are still students who are not open to the problems they face, both in the school environment and in the community environment and the general way the problems in this research are: 1 . What are the factors for the occurrence of juvenile delinquency in class X SMK Negeri 1 Sipirok? 2. How is the implementation of group guidance services in reducing the delinquency of class $X$ students of SMK Negeri 1 Sipirok. The objectives to be achieved are: 1. To find out the factors that cause juvenile delinquency in class X SMK Negeri 1 Sipirok. 2. To find out the implementation of group guidance services in reducing delinquency in class $X$ students of SMK Negeri 1 Sipirok. The research method used was True experimental design in the form of preetest-posttest Control Group Design. With a sample of the experimental class, namely X-1 as many as 10 students and the control class, namely X-2 as many as 10 students, so the total sample is 20 students. The group guidance service was carried out three times, namely in the first meeting carrying out the pre-test, the second providing group guidance services and the third conducting the post-test. This data was analyzed using the Wilcoxon signed ranks test formula and Kolmogorov Smitnov $Z$ with the help of SPSS version 20.00. The findings in the experimental group and the control group there was a significant increase between the results of the control pre-test and the experimental post-test. The average juvenile delinquency variable is 143.5000 (posttest experiment) while the control class is 141.1000. (posttest control) this shows a very significant difference.
\end{abstract}

Keywords: Juvenile Delinquency and Group Guidance

\begin{abstract}
Abstrak: Penelitian ini didasarkan atas permasalahan masih adanya siswa yang tidak terbuka dengan masalah yang dihadapinya, baik dilingkungan sekolah maupun di dalam lingkungan masyarakat dan cara umum permasalahan penelitian ini adalah : 1 . Apa yang menjadi faktorfaktor terjadinya kenakalan remaja kelas X SMK Negeri 1 Sipirok ? 2. Bagaimana Pelaksanaan layanan bimbingan kelompok dalam mengurangi kenakalan siswa kelas X SMK Negeri 1 Sipirok. Tujuan yang ingin dicapai adalah : 1 . Untuk mengetahui faktor-faktor yang menjadi penyebab terjadinya kenakalan remaja kelas X SMK Negeri 1 Sipirok. 2. Untuk mengetahui pelaksanaan layanan bimbingan kelompok dalam mengurangi kenakalan siswa kelas X SMK Negeri 1 Sipirok. Metode penelitian yang digunakan True experimental design dengan bentuk preetest-posttest Control Group Design. Dengan sampel kelas eksperimen yaitu X-1 sebanyak 10 siswa dan kontrol yaitu kelas X-2 sebanyak 10 siswa sehingga jumlah sampel 20 siswa. Layanan bimbingan kelompok dilakukan sebanyak tiga kali, yakni dalam pertemuan pertama melaksanakan preetest, kedua melakukan pemberian layanan bimbingan kelompok dan ketiga melakukan posttest. Data ini di analisis dengan menggunakan rumus wilcoxon signed ranks test dan kolmogorov smitnov $Z$ dengan bantuan SPSS versi 20.00. Hasil temuan pada kelompok eksperimen dan kelompok kontrol terdapat peningkatan yang signifikan antaran hasil preetest kontrol dan posttest eksperimen. Rata-rata variabel kenakalan remaja sebesar 143.5000 (posttest eksperimen) sedangkan kelas control 141.1000. (posttest kontrol) ini terlihat perbedaan yang sangat signifikan.
\end{abstract}

Kata Kunci: Kenakalan Remaja dan Bimbingan Kelompok. 


\section{PENDAHULUAN}

Sekolah Menengah Pertama Madrasah Tsanawiyah merupakan lembaga lanjutan pertama setelah menyelesaikan pendidikan dasar dan pada masa ini tenaga pendidik seharusnya tidak hanya memperhatikan proses belajar mengajar saja, namun hendaknya juga memperhatikan perkembangan peserta didiknya yang telah memasuki usia remaja mengingat maraknya kejahatan yang dilakukan anak usia remaja atau yang sering disebut dengan kenakalan remaja.

Menurut Walgito dalam Musbikin (2013 : 13) tiap-tiap perbuatan itu dilakukan oleh orang dewasa, maka perbuatan itu merupakan kejahatan, jadi perbuatan yang melawan hukum yang dilakukan oleh anak, khususnya anak remaja.

Saat sekarang ini banyak siswa yang seharusnya berada di sekolah untuk menuntut ilmu malah keluyuran di luar sekolah dengan melakukan berbagai kegiatan yang melenceng dari kewajibannya sebagai siswa. Misalnya tawuran, melakukan perbuatan mesum di warung internet, memakai obat-obatan terlarang dan lain sebagainya. Keadaan seperti ini juga terjadi di SMK Negeri 1 Sipirok walaupun tidak separah yang terjadi di ibukota. Sebahagian siswa masih ada yang tidak berada di lingkungan sekolah disaat proses belajar mengajar berlangsung dan melakukan tindakan terlarang yang tidak seharusnya dilakukan di lingkungan sekolah. Kenakalan remaja khususnya yang terjadi di lingkungan sekolah merupakan tanggung jawab bersama untuk segera diselesaikan salah satunya dengan peran guru bimbingan dan konseling. Beberapa layanan bimbingan dan konseling dirasa mampu untuk menyelesaikan atau mengurangi kasus kenalan remaja di sekolah di antaranya dengan layanan bimbingan kelompok.

Menurut Tohirin

(2011:22)

Bimbingan dan Konseling yang dahulu dikenal dengan nama Bimbingan dan Penyuluhan (Guidance and Conseling), merupakan bagian tak terpisahkan dari sebuah sistem pendidikan. Sebagai sebuah sistem, kehadirannya diperlukan dalam upaya pembimbingan sikap perilaku siswa terutama dalam menghadapi perubahan-perubahan dirinya dari anak-anak menuju jenjang usia yang lebih dewasa Bimbingan Konseling terdapat Satu jenis layanan yang dinamakan Layanan Bimbingan Kelompok. Bimbingan kelompok merupakan satu layanan bimbingan dan konseling yang diberikan kepada siswa dalam bentuk kelompok untuk membahas masalah / topik umum atau mengalami masalah yang sama secara luas dan mendalam yang bermanfaat bagi anggota kelompok.

Gazda (2004:309) mengemukakan bahwa bimbingan kelompok di sekolah merupakan kegiatan informasi kepada sekelompok siswa untuk membantu mereka menyusun rencana dan keputusan yang tepat. Gazda juga menyebutkan bahwa bimbingan kelompok diselenggarakan untuk memberikan informasi yang bersifat personal, vokasional, dan sosial. 
Bimbingan Kelompok dilaksanakan Sehingga dengan latar belakang masalah dalam bentuk kelompok yang terdiri dari 10-15 yang diuraiakan di atas, penulis tertarik untuk orang anggota kelompok yang dipimpin oleh melakukan penelitian dengan judul pemimpin kelompok (guru BK atau Konselor) "Pelaksanaan Layanan Bimbingan dan dimana bentuk kegiatannya menggunakan Kelompok Untuk Mengurangi Tingkat dinamika kelompok. Dalam pelaksanannya, Kenakalan Remaja di SMK Negeri 1 Sipirok" anggota kelompok membahasa sebuah topik yang teraktual berdasarkan kesepakatan METODE anggota kelompok. Sehingga memungkinkan Jenis penelitian yang digunakan dalam untuk setiap anggoa kelompok memperoleh penelitian ini adalah penelitian kuantitatif informasi dari anggota kelompok. Sehingga eksperimen. Metode penelitian kuantitatif infromasi yang diperoleh langsung di peroleh merupakan salah satu jenis penelitian yang peserta kelompok. Dengan demikian bimbingan spesifikasinya adalah sistematis, terencana dan kelompok akan lebih cepat mencapai sasaran terstruktur dengan jelas sejak awal hingga terutama mengenai perkembangan peserta didik, pembuatan desain penelitiannya. Metode yang mereka sendiri mengalami masalahnya. penelitian kuantitatif, sebagaimana Fenomena yang penulis lihat di SMK dikemukakan oleh Sugiyono (2011: 8) yaitu : Negeri 1 Sipirok masih banyaknya siswa yang "Metode penelitian yang berlandaskan pada datang terlambat pada pagi hari khususnya pada filsafat positivisme, digunakan untuk meneliti hari-hari tertentu yang memang pada hari pada populasi atau sampel tertentu, tersebut jam masuk sekolah lebih cepat pengumpulan data menggunakan instrumen dibandingkan pada hari lainnya, masih adanya penelitian, analisis data bersifat siswa yang sering bolos pada saat jam pelajaran kuantitatif/statistik, dengan tujuan untuk berlangsung hingga pulang sekolah atau menguji hipotesis yang telah ditetapkan". kembali masuk saat pergantian jam pelajaran, dan juga perkelahian dengan sesama siswa.

Populasi dalam penelitian ini adalah Identifikasi masalah dalam penelitian ini adalah: beberapa remaja yang ada di SMK Negeri 1 Sipirok. Untuk lebih jelas dapat dilihat pada tabel berikut :

1. Banyaknya siswa kelas X SMK Negeri

1 Sipirok sering terlambat.

2. Banyaknya siswa kelas $X$ SMK Negeri 1 Sipirok sering absen/bolos.

3. Perkelahian sesama siswa kelas X SMK Negeri 1 Sipirok. 
Tabel 1

Populasi Penelitian

Observasi langsung oleh penulis

\begin{tabular}{|c|c|c|c|}
\hline $\begin{array}{c}\text { SMK } \\
\text { Negeri } \\
\begin{array}{c}\mathbf{1} \\
\text { Sipirok }\end{array}\end{array}$ & $\begin{array}{c}\text { Laki- } \\
\text { laki }\end{array}$ & $\begin{array}{l}\text { Perempua } \\
\text { n }\end{array}$ & Jumlah \\
\hline $\mathrm{X}-1$ & 16 & 17 & 33 \\
\hline $\mathrm{X}-2$ & 16 & 17 & 33 \\
\hline $\mathrm{X}-3$ & 16 & 17 & 33 \\
\hline $\mathrm{X}-4$ & 16 & 17 & 33 \\
\hline Jumlah & & & $\mathbf{1 3 2}$ \\
\hline
\end{tabular}

Observasi langsung oleh penulis

Dalam penelitian ini, maka sampel yang diambil adalah sebagian remaja yang ada di SMK Negeri 1 Sipirok yang berjumlah 20 remaja. Untuk lebih jelas dapat dilihat pada tabel berikut:

Tabel 2. Sampel Penelitian

\begin{tabular}{|l|c|l|c|l|}
\hline $\begin{array}{l}\text { SMK } \\
\text { NEGERI 1 } \\
\text { SIPIROK }\end{array}$ & L & JUMLAH & $\begin{array}{l}\text { KETERANGA } \\
\text { N }\end{array}$ \\
\hline X-1 & 7 & 3 & 10 & EKSPERIMEN \\
\hline X-2 & 5 & 5 & 10 & KONTROL \\
\hline \multicolumn{2}{|l|}{ JUMLAH } & 20 \\
\hline
\end{tabular}

Teknik pengambilan sampel yang digunakan dalam penelitian ini adalah teknik non random sampling dengan metode sampling purposif (purposive sampling). Menurut

Suharsimi A (2006:132) sampling purposive adalah pemilihan sekelompok subyek didasarkan atas ciri-ciri atau sifat-sifat tertentu yang dipandang mempunyai sangkut paut yang erat dengan ciri-ciri atau sifat populasi yang sudah diketahui sebelumnya.
Teknik analisi statistik yang digunakan untuk menguji dalam penelitian ini adalah dengan menggunakan Wilcoxon Signed Rank Data test dan Kolmogorof Smirnov.

\section{HASIL}

Penelitian ini bertujuan untuk megurangi tingkat kenakalan remaja melalui layanan bimbingan kelompok. Data yang diperoleh merupakan hasil preetest dan posttest yang berkaitan dengan megurangi tingkat kenakalan remaja. Instrumen yang digunakan adalah angket.

Berdasarkan data yang diperoleh, maka didapatkan hasil penelitian sebelum dilakukan preetest dan setelah diberikan perlakuan dan posttest dimana data kuantitatif diolah dengan menggunakan SPSS 20.0 for Windows.

\begin{tabular}{|c|c|c|c|c|c|}
\hline \multirow{2}{*}{$\begin{array}{l}\mathrm{N} \\
\mathrm{O}\end{array}$} & \multirow{2}{*}{$\begin{array}{l}\text { INDIKA } \\
\text { TOR }\end{array}$} & \multicolumn{2}{|c|}{$\begin{array}{l}\text { KELAS } \\
\text { EKSPERIMEN }\end{array}$} & \multicolumn{2}{|c|}{$\begin{array}{l}\text { KELAS } \\
\text { KONTROL }\end{array}$} \\
\hline & & $\begin{array}{l}\text { PREE } \\
\text { TEST }\end{array}$ & $\begin{array}{l}\text { POST } \\
\text { TEST }\end{array}$ & $\begin{array}{l}\text { PREE } \\
\text { TEST }\end{array}$ & $\begin{array}{l}\text { POST } \\
\text { TEST }\end{array}$ \\
\hline 1. & $\begin{array}{l}\text { FRUST } \\
\text { ASI }\end{array}$ & 174 & 210 & 121 & 206 \\
\hline 2. & $\begin{array}{l}\text { MENGI } \\
\text { SOLASI } \\
\text { DRI }\end{array}$ & 186 & 235 & 172 & 220 \\
\hline 3. & AGRESI & 146 & 189 & 151 & 181 \\
\hline 4. & $\begin{array}{l}\text { KELUA } \\
\text { RGA }\end{array}$ & 176 & 206 & 153 & 198 \\
\hline 5. & $\begin{array}{l}\text { LINGK } \\
\text { UNGAN } \\
\text { MASYA } \\
\text { RAKAT } \\
\end{array}$ & 208 & 256 & 196 & 240 \\
\hline 6. & $\begin{array}{l}\text { LINGK } \\
\text { UNGAN } \\
\text { SEKOLA } \\
\mathrm{H} \\
\end{array}$ & 161 & 195 & 139 & 190 \\
\hline J & $\mathrm{LAH}$ & 1160 & 1432 & 1023 & 1353 \\
\hline
\end{tabular}


1. Perbandingan Hasil Penelitian Kelas Eksperimen dan Kelas Kontrol

Tabel 1

\section{Perbandingan Hasil Penelitian}

Setelah adanya tabulasi hasil penelitian megurangi tingkat kenakalan remaja pada indikator yang pertama yaitu frustrasi seperti apadiri saya pada kelas eksperimen yang hasil preetestnya 174 sedangkan hasil posttestnya

210 pada indikator ini terdapat peningkatan, sedangkan pada kelas kontrol hasil preetestnya 121 dan hasil posttestnya sebesar 206 yang juga menunjukan peningkatan. Jadi, dapat disimpulkan pada indikator pertama hasil kelas eksperimen lebih tinggi dari kelas kontrol.

Pada indikator yang kedua yaitu mengisolasi diri pada kelas eksperimen yang hasil preetest pada kelas eksperimen adalah 186 dan hasil posttestnya 235 dan terjadi peningkatan. Pada kelas kontrol hasil preetestnya 172 dan hasil posttestnya 220 sehingga menunjukan adanya peningkatan. Jadi, dapat disimpulkan pada indikator kedua hasil kelas eksperimen lebih tinggi pada dari kelas kontrol.

Pada Indikator yang ketiga yaitu agresi hasil preetest pada kelas eksperimen adalah 146 dan hasil posttestnya 189. Pada kelas kontrol hasil preetestnya 151 dan hasil posttestnya 181.Jadi, dapat disimpulkan pada indikator ketiga hasil kelas eksperimen lebih tinggi pada dari kelas kontrol.

Pada Indikator yang keempat yaitu keluarga pada kelas eksperimen adalah 176 dan hasil posttestnya 206 ini menunjukan adanya peningkatan hasil. Pada kelas kontrol hasil preetestnya 153 dan hasil posttestnya 198 menunjukan adanya peningkatan hasil test. Jadi, dapat disimpulkan pada indikator keempat ini hasil dari kelas eksperimen lebih tinggi pada dari kelas kontrol. Pada Indikator yang kelima yaitu lingkungan masyarakat didapatkan hasil preetest pada kelas eksperimen adalah 208 dan hasil posttestnya 256. Pada kelas kontrol hasil preetestnya 196 dan hasil posttestnya 240 menunjukan adanya peningkatan hasil test. Jadi, dapat disimpulkan pada indikator kelima ini hasil dari kelas eksperimen lebih tinggi pada dari kelas kontrol.

Pada Indikator yang keenam yaitu lingkungan sekolah dapat dipercaya dengan cara menerima dan mendukung anda, bekerja sama dengan anda, bersikap terbuka dengan anda didapatkan hasil preetest pada kelas eksperimen adalah 161 dan hasil posttestnya 195. Pada kelas kontrol hasil preetestnya 139 dan hasil posttestnya 190 menunjukan adanya peningkatan hasil test. Jadi, dapat disimpulkan pada indikator keenam ini hasil dari kelas eksperimen lebih tinggi pada dari kelas kontrol.

Dari hasil perbandingan antara kelas eksperimen dengan kelas kontrol, menunjukan bahwa hasil penelitian pada kelas eksperimen lebih tinggi dari pada hasil penelitian pada kelas kontrol. Dengan demikian peneliti dapat menyimpulkan layanan bimbingan kelompok yang dilakukan peneliti lebih besar pengaruhnya untuk megurangi tingkat kenakalan remaja siswa. 
Rumus yang digunakan untuk menghitung rata-rata hasil penelitian kelas eksperimen dan kelas kontrol adalah sebagai berikut:

Skor yang diperoleh =
$\frac{\text { hasil penelitian }}{\text { jumlah item }} \times 2$

Tabel 2

Gambar 1 Grafik Batang Mengurangi Tingkat Kenakalan Remaja

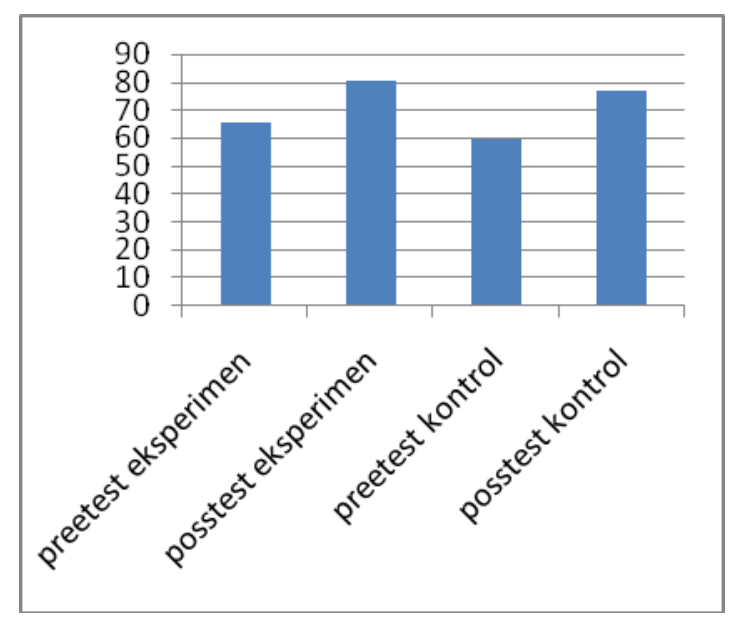

Dari gambar 1, diperoleh nilai rata-rata Eksperimen-Kontrol siswa kelas X1 dan X-2 yaitu eksperimen Pretest 65,66 eksperimen Posttes 80,68 dan kontrol Pretest 59,64 kontrol Posttes 77,18. Berdasarkan interpal perbandingan hasil tabel 2 maka EksperimenKontrol di SMK Negeri 1 Sipirok berada pada tingkat sangat baik.

Pengujian hipotesis ini dilakukan dengan teknik analisis statistik wilcoxon signed rank test melalui program SPSS versi 20.00 .

Dari hasil pengolahan tersebut diperoleh hasil penghitungan seperti yang tercantum pada tabel berikut ini:
Tabel 3

Hasil Analisis Wilcoxon Signed Rank Test Perbedaan Dalam Mengurangi Tingkat Kenakalan Remaja Pada Preetest Dan Posttest Kelas Eksperimen

\section{Test Statistics ${ }^{\mathrm{a}}$}

\begin{tabular}{|l|r|}
\hline & $\begin{array}{c}\text { posstest - } \\
\text { preetest }\end{array}$ \\
\hline$Z$ & $-2,803^{\mathrm{b}}$ \\
$\begin{array}{l}\text { Asymp. Sig. (2- } \\
\text { tailed) }\end{array}$ &, 005 \\
\hline
\end{tabular}

a. Wilcoxon Signed Ranks Test

b. Based on negative ranks.

Berdasarkan tabel di atas, bahwa skor z sebesar $-2,803^{\mathrm{b}}$ dengan signifikan ,005 sehinga, dapat disimpulkan bahwa hipotesis pertama yang diuji dalam penelitian ini dapat diterima, yaitu "Ada perbedaan megatasi kenakalan remaja di berikan layanan bimbingan kelompok dalam kelas eksperimen." Untuk selanjutnya, perlu diketahui apakah preetest dan posttest dapat dilihat tabel di bawah ini. 
Tabel 4

Arah Perbedaan Preetest Dan Posttest Untuk Mengurangi

Tingkat Kenakalan Remaja

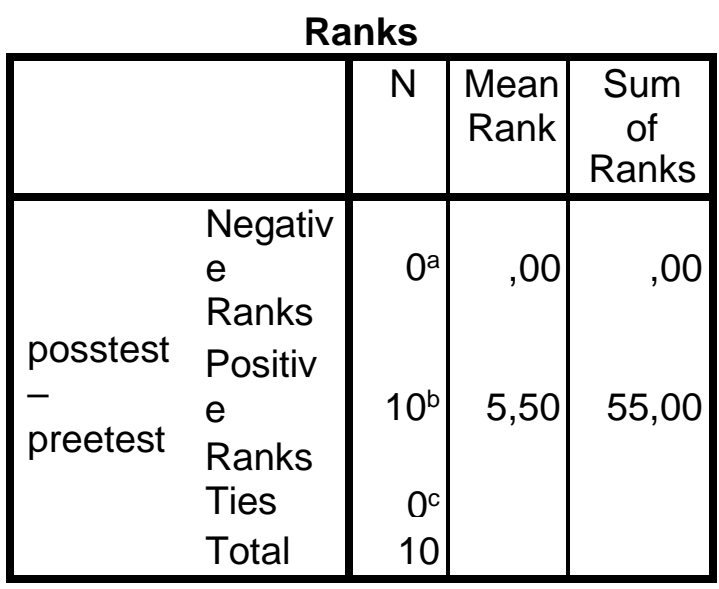

a. posstest < preetest

b. posstest $>$ preetest

c. posstest $=$ preetest

Berdasarkan data pada tabel di atas dapat diartikan bahwa 10 siswa pada kelompok eksperimen, sebanyak 10 siswa tersebut seluruhnya mengalami peningkatan pemahaman tentang Mengurangi tingkat kenakalan remaja hasil preetest ke posttest. Hal tersebut juga dapat diartikan bahwa kelas eksperimen mengalami peningkatan pemahaman tentang Mengurangi tingkat kenakalan remaja setelah mendapat perlakuan layanan bimbingan kelompok.
Tabel 5

Hasil Analisis Wilcoxon Signed Rank Test Perbedaan Mengurangi Kenakalan Remaja Pada Preetest Dan Posttest Kelas Kontrol

Test Statistics ${ }^{a}$

\begin{tabular}{|l|r|}
\hline & $\begin{array}{r}\text { posstest }- \\
\text { preetest }\end{array}$ \\
\hline$Z$ & $-2,803^{\mathrm{b}}$ \\
$\begin{array}{l}\text { Asymp. Sig. (2- } \\
\text { tailed) }\end{array}$ &, 005 \\
\hline
\end{tabular}

a. Wilcoxon Signed Ranks

Test

b. Based on negative ranks.

Berdasarkan tabel di atas dapat dilihat bahwa skor $\mathrm{z}$ sebesar $-2,803^{\mathrm{b}}$ dengan signifikan 005 dari hasil analisis statistik ada perbedaan Mengurangi tingkat kenakalan remaja di berikan layanan bimbingan kelompok dalam kelompok eksperimen dan kontrol. Sehingga dapat disimpulkan bahwa hipotesis ke 2 yang diuji dalam penelitian ini diterima “. karena adanya Mengurangi tingkat kenakalan remaja dengan di berikan layanan bimbingan kelompok pada kelompok eksperimen dan kelompok kontrol.

Perbedaan peningkatan mengurangi tingkat kenakalan remaja pada kelompok eksperimen sebelum (preetest) dan sesudah (posstest) mengikuti kegiatan layanan bimbingan kelompok. Hasil dari pengujian analisis diperoleh bahwa peningkatan mengurangi tingkat kenakalan remaja dapat ditingkatkan dengan menggunakan layanan 
bimbingan kelompok. Sehingga terbukti bahwa layanan bimbingan kelompok efektif untuk mengurangi tingkat kenakalan remaja.

Gazda (2004:309) mengemukakan bahwa bimbingan kelompok di sekolah merupakan kegiatan informasi kepada sekelompok siswa untuk membantu mereka menyusun rencana dan keputusan yang tepat. Gazda juga menyebutkan bahwa bimbingan kelompok diselenggarakan untuk memberikan informasi yang bersifat personal, vokasional, dan sosial.

Setelah adanya tabulasi hasil penelitian mengurangi tingkat kenakalan remaja pada indikator yang pertama yaitu menyadari diri sendiri, siapa saya, seperti apa diri saya pada kelas eksperimen yang hasil preetestnya 174 sedangkan hasil posttestnya 210 pada indikator ini terdapat peningkatan, sedangkan pada kelas kontrol hasil preetestnya 121 dan hasil posttestnya sebesar 206 yang juga menunjukan peningkatan. Jadi, dapat disimpulkan pada indikator pertama hasil kelas eksperimen lebih tinggi dari kelas kontrol.

Pada indikator yang kedua yaitu menerima diri sendiri, menyadari aneka kekuatan daan kemampuan saya pada kelas eksperimen yang hasil preetest pada kelas eksperimen adalah 186 dan hasil posttestnya 235 dan terjadi peningkatan. Pada kelas kontrol hasil preetestnya 172 dan hasil posttestnya 220 sehingga menunjukan adanya peningkatan. Jadi,dapat disimpulkan pada indikator kedua hasil kelas eksperimen lebih tinggi pada dari kelas kontrol.

Pada Indikator yang ketiga yaitu mempercayai anda untuk menerima dan mendukung saya, bekerja sama dengan saya, bersikap terbuka dengan saya hasil preetest pada kelas eksperimen adalah 146 dan hasil posttestnya 189. Pada kelas kontrol hasil preetestnya 151 dan hasil posttestnya 181.Jadi, dapat disimpulkan pada indikator ketiga hasil kelas eksperimen lebih tinggi pada dari kelas kontrol.

Pada Indikator yang keempat yaitu menyadari orang lain, siapa anda, seperti apa diri anda pada kelas eksperimen adalah 176 dan hasil posttestnya 206 ini menunjukan adanya peningkatan hasil. Pada kelas kontrol hasil preetestnya 153 dan hasil posttestnya 198 menunjukan adanya peningkatan hasil test. Jadi, dapat disimpulkan pada indikator keempat ini hasil dari kelas eksperimen lebih tinggi pada dari kelas kontrol.

Pada Indikator yang kelima yaitu menerima diri anda, menyadari naeka kekuatan dan kemampuan anda didapatkan hasil preetest pada kelas eksperimen adalah 208 dan hasil posttestnya 256. Pada kelas kontrol hasil preetestnya 196 dan hasil posttestnya 240 menunjukan adanya peningkatan hasil test. Jadi, dapat disimpulkan pada indikator kelima ini hasil dari kelas eksperimen lebih tinggi pada dari kelas kontrol.

Pada Indikator yang keenam yaitu dapat dipercaya dengan cara menerima dan mendukung anda, bekerja sama dengan anda, 
bersikap terbuka dengan anda didapatkan hasil preetest pada kelas eksperimen adalah 161 dan hasil posttestnya 195. Pada kelas kontrol hasil preetestnya 139 dan hasil posttestnya 190 menunjukan adanya peningkatan hasil test. Jadi, dapat disimpulkan pada indikator keenam ini hasil dari kelas eksperimen lebih tinggi pada dari kelas kontrol.

Dari skor yang diperoleh masing-masing indikator terlihat adanya peningkatan mengurangi tingkat kenakalan remaja dengan diberikannya perlakuan layanan bimbingan kelompok pada kelompok eksperimen dan kelompok kontrol. Hasil dari pengujian hipotesis diperoleh bahwa mengurangi tingkat kenakalan remaja dapat ditingkatkan dengan menggunakan layanan bimbingan kelompok. Sehingga terbukti bahwa layanan bimbingan kelompok efektif untuk mengurangi tingkat kenakalan remaja.

\section{KESIMPULAN}

Kesimpulan umum dari penelitian ini adalah layanan bimbingan kelompok dan layanan informasi sama-sama efektif untuk meningkatkan mengurangi tingkat kenakalan remaja.

Secara khusus penelitian ini dapat disimpulkan :

1. Adanya peningkatan mengurangi tingkat kenakalan remaja diberikan layanan bimbingan kelompok pada kelompok eksperimen dan kelompok kontrol setelah (preetest) mengikuti kegiatan bimbingan kelompok.

2. Terdapat peningkatan pelaksanaan layanan bimbingan kelompok dalam mengurangi tingkat kenakalan remaja.

\section{KEPUSTAKAAN}

Gazda, 2004. Manfaat Bimbingan Kelompok.

Palembang: Rajawali Pers

Imam Musbikin, 2013. Kenakalan Remaja.

Jakarta: PT Gramedia Pustaka Utama

Sugiyono. 2011. Metode Penelitian Bisnis, Bandung :Alfabeta.

Suharsimi, A. 2006. Prosedur Penelitian Suatu Pendekatan Praktik, Jakarta: RinekaCipta.

Tohirin. 2011. Bimbingan dan Konseling Di Sekolah. Jakarta: Rajawali. 